\title{
MAN AND MACHINE IN MACROECONOMICS
}

\author{
BY KEVIN D. HOOVER
}

CHOPE Working Paper No. 2012-07

August 2012

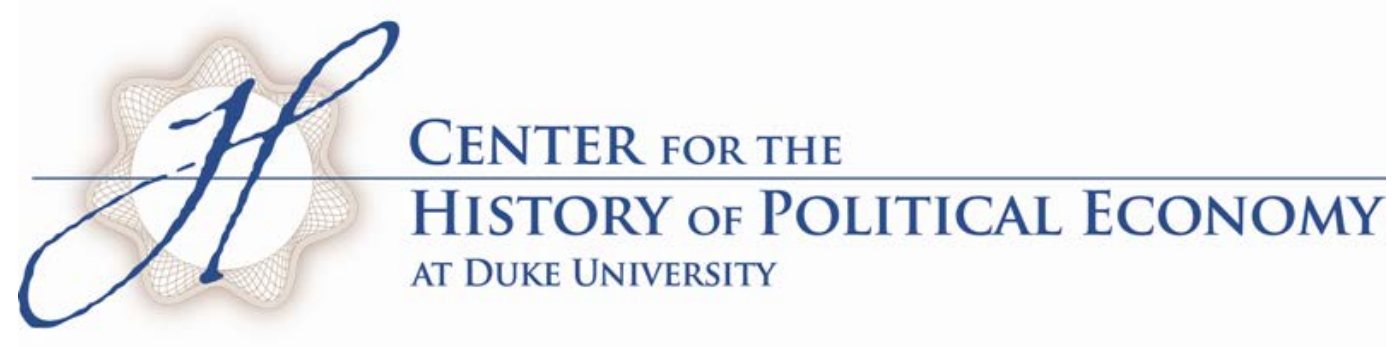




\title{
Man and Machine in Macroeconomics*
}

\author{
Kevin D. Hoover \\ Department of Economics and Department of Philosophy \\ Duke University \\ Box 90097 \\ Durham, North Carolina 27708-0097
}

Tel. (919) 660-1876

E-mail kd.hoover@duke.edu

7 August 2012

*Plenary lecture delivered to the Colloque de l'Association Charles Gide pour l'Histoire de la Pensée Economomique, 7-9 June 2012, Université de Nice Sophia Antipolis. An earlier version was delivered in the New Directions in Economics public lecture series at Boston University, 17 November 2010. 


\section{Abstract \\ of \\ Man and Machine in Macroeconomics}

The potted histories of macroeconomics textbooks are typically Keynes-centric. Keynes is credited with founding macroeconomics, and the central developments in the field through the early 1970s, including large-scale macroeconometric models are usually termed "Keynesian.” The story of macroeconomics is framed as support or opposition (e.g., monetarism or the new classical macroeconomics) to Keynes. The real story is more complicated and involves at least two distinct threads. Keynes was important, but perhaps more important for the detailed development of the field were the early macroeconometricians - Ragnar Frisch and Jan Tinbergen. Frisch and Tinbergen adopted physical or mechanical metaphors in which aggregate quantities are central. Keynes's vision of macroeconomics is better described as "medical." It is based in human psychology and individual decision-making and sees the economy as an organic system. Whereas policymakers and economic advisers in Keynes view can operate only within the economic system, Frisch and Tinbergen laid the basis for an optimal-control approach to economic policy in which the policymaker stands outside the system. Recent new classical macroeconomics has adopted an uneasy amalgam of the medical and mechanical metaphors.

Keywords: macroeconomics, Keynes, Frisch, Tinbergen, Klein, macroeconometric models, macroeconomic policy

JEL Codes: B22, B23 


\section{Man and Machine in Macroeconomics}

\section{Prologue}

The Great Recession and worldwide Financial Crisis promoted soul-searching among economists and scapegoating among the public, from taxi drivers to heads of state: The Queen of England met with a gathering of economists at the London School of Economics to discuss the financial collapse: "Why,” she asked, “did nobody notice it?" Despite our disappointing record as prognosticators, the public still expects economists to tell them how to extricate the economy from its current doldrums.

There is an element of magical thinking in these demands. In the United States, we see it in the notion that our president or the chairman of the Federal Reserve is directly responsible for the success or failure of the economy. Responsibility is more diffuse in the European Union, but I would be surprised if public's expectations of Brussels or Frankfurt are not similar. And I presume that one reason that the French President Sarkosky was not reelected was that he was held responsible for the ills of the French and European economies. I don't want to deny that leading politicians or central bankers are important players for good or ill; but, as I ask my students, if a president could set the economic dial as a matter of unfettered choice, why would the economy ever fare poorly? (Sometimes they would answer that George Bush was a bad man or that Vice President Richard Cheney benefited in some sinister way from bad economic times. But once Barack Obama became the American president and American economy still performed badly, I heard that less often.)

The notion that an economy is an object to be controlled by policy is pervasive. There are two dominant metaphors. The first sees the economy as a machine operated by 
the government: economists and policymakers as engineers. The second sees the economy as an organic entity. Bill Clinton campaigned for the American presidency in 1992 on a set of policies that he said would "grow the economy": economists and policymakers as farmers. Clinton's phrase is now ubiquitous; but it rings false in my ears - not, as I once thought, because it is ungrammatical, we naturally talk of farmers growing crops - but because, even if one accepts an organic metaphor, it seems like the wrong metaphor. Another organic metaphor that works better, perhaps, sees the economy as a body: economists and policymakers as physicians.

Esteem for John Maynard Keynes has ever ebbed and flowed. Since the onset of the Great Recession and the Financial Crisis, Keynes - never an obscure figure among economists - became ever more familiar to the general public. In the two years after the onset of the recession, Keynes was mentioned in print media more than three times more frequently than in the two years before the recession - the total number of mentions runs into the thousands per year. ${ }^{1}$ Keynes, the economic hero; Keynes, the economic knave. Take your pick.

Reaching a nadir in the last heady days of the boom, Keynesian economics was again in vogue with the recession of 2007 and the financial collapse of 2008, only to become embattled with rising deficits and continued slow growth despite the stimulus. The Wall Street Journal often reminds us that Keynes is dead. In an article in the New York Times, N. Gregory Mankiw (2008), Harvard economics professor and former chairman of George W. Bush's Council of Economic Advisors, found a well worn passage from Keynes's masterwork, The General Theory of Employment Interest and Money, that

\footnotetext{
${ }^{1}$ Based on a search of the Lexis database.
} 
speaks to our time:

"At the present moment people are unusually expectant of a more fundamental diagnosis; more particularly ready to receive it; eager to try it out, if it should be even plausible. But apart from this contemporary mood, the ideas of economists and political philosophers, both when they are right and when they are wrong, are more powerful than is commonly understood. Indeed the world is ruled by little else. Practical men, who believe themselves to be quite exempt from any intellectual influences, are usually the slaves of some defunct economist. Madmen in authority, who hear voices in the air, are distilling their frenzy from some academic scribbler of a few years back.” [Keynes 1936, p. 383; quoted by Mankiw 2008]

Keynes himself is now that defunct economist. The Wall Street Journal knows that he is defunct, but fears that - zombie-like - he won’t stay down. Mankiw too knows that he is defunct, but sees Caspar, the friendly ghost.

Without diminishing Keynes’s importance, I want to suggest that the story of macroeconomics is more complex than generally appreciated and that there are other economists from whom macroeconomists and policymakers - practical and mad - are distilling their frenzy and their wisdom.

\section{The Potted History of Macroeconomics}

Economists are typically both ignorant and unappreciative of the history of their discipline. Yet, economists, like the practitioners of other fields, convey a potted version of that history their students. The potted history is easily discovered through quick perusal of macroeconomics textbooks.

I don't need to recount the fine details of this potted history: we all know it. Broadly it goes like this: Once upon a time, economists were the champions of laissez faire. Then, along came the Great Depression. Keynes declared the end of laissez faire and provided us in his General Theory with an alternative. Thus, in creating the 
antithesis between microeconomics and macroeconomics, Keynes created a dialectical tension that Paul Samuelson then resolved with his neoclassical synthesis. And then Keynesian economics ruled the policy roost. But Keynes provided no theory of inflation. Phillips introduced his curve and provided policymakers with an instrument through which they could exchange inflation for unemployment. But Cassandra in the form of Milton Friedman presciently warned that the heady days of aggregate demand management would lead to the collapse of the Keynesian economists' Troy. The stagflation of the early 1970s blasted holes in the ramparts of Keynesian economic management, and Friedman's monetarism was there to fill the breach. But Friedman's monetarism did not get to the root of the problem with Keynes: real economics is microeconomics and - despite Samuelson's irenic doctrine of the neoclassical synthesis Keynes failed to build on adequate microfoundations. Robert Lucas, Thomas Sargent and others introduced the new classical macroeconomics, which supported monetarists policies, but did so on a rigorous microfoundational analysis. Nostalgic for Keynesian policy conclusions, the New Keynesians adopted New Classical microfoundational methods while still addressing the problems of market failures. With that, we have reached the situation of macroeconomics today - at least as it is taught to undergraduate and graduate students alike.

I cannot begin to say all that is wrong with this potted history. But, love him or hate him, please note that Keynes stands at its center. And while no story maintains its currency for long if it is totally unconnected to the truth, this story is misleading or wrong in nearly every respect - not least in its dramatis personae. At a bare minimum, we must add the names of Ragnar Frisch and Jan Tinbergen to the history of macroeconomics. 
Most of the pieces of the alternative story have been noticed by other scholars, but rarely have the pieces been put together. And I believe that they should be put together to craft a different history for macroeconomics - one in which Keynes remains important, but not preeminent, and one in which a tension between competing visions of macroeconomics is central. One result of this reappraisal will be to present Keynes as a substantially different thinker than he is regarded in our potted textbook histories.

\section{The Mechanical Vision}

The phenomena that we now recognize as macroeconomic - inter alia inflation, growth, mass unemployment, the balance of payments, interest rates, and exchange rates - are among the longest recognized and longest analyzed in the history of economics. Theories of the relationship of inflation to money clearly related to those of modern economics go back at least to the $16^{\text {th }}$ century. But it was not until the 1930s that economists thought address them through a special subdiscipline called macroeconomics. One problem that worried economists of the 1920s, even before the Great Depression, was the trade cycle or, as we now call it the business cycle - the alternation of good and bad times.

The puzzle was, how should we begin to think of business cycles. There were at least three options:

- First, they might be intrinsic to the structure of the economy;

- Second, they might be merely the cumulation of random influences;

- Third, they might be the complex implications of human actions in an unrepeatable historical setting.

The first two options could be regarded as analogous to physical dynamics - a pattern 
such as the tides or the amplitude of the string of a musical instrument.

The Norwegian economist Ragnar Frisch and the Dutch economist Jan Tinbergen were deeply influenced by such physical metaphors. Frisch and Tinbergen are not so well known as Keynes, even to economists. A search in the Econlit database for articles with their names in the titles produces 75 for Frisch, 117 for Tinbergen, and 1,978 for Keynes. Yet, they are not altogether uncelebrated. Strikingly, it was not Samuelson, but Ragnar Frisch and Jan Tinbergen who shared the very first Nobel Prize in Economics in 1969.

\section{FRISCH}

Frisch was born in Oslo in 1895 and trained as a goldsmith. He entered university only at the age of 21 and chose economics as it was regarded as an easy subject and the path to a quick degree. He was drawn to mathematics and statistics and joined the then small group of mathematical economists.

As he saw it, earlier mathematical economists (e.g., Cournot and Walras) had satisfactorily analyzed exchange at a single period; so the key problem was to deal with economic decision-making over time. The first problem analogized to the problem of statics in physics; the second, to the problem of dynamics. And the physicists had already done the math. When Frisch began to analyze the business cycle, he began by thinking of pendulums. ${ }^{2}$ The swing of a simple pendulum is too regular; so, he analyzed the movements of complex pendulums and worked out the mathematics of their cycles. In a famous paper, he analogized the business cycle to a rocking horse that is given a push from time to time. The rocking horse itself captured the intrinsic dynamics of the

\footnotetext{
${ }^{2}$ See, for example, Frisch (1933).
} 
cycle (what he calls the propagation mechanism), while the irregular pushes (what he calls the impulses) corresponded to various random shocks to the economic system. In this metaphor Frisch ties together his interests in physical dynamics and statistics. Frisch was explicit: economics was social physics.

Frisch is a central, if neglected, figure in shaping modern economics. He was the moving force behind the Econometric Society - the group dedicated to promoting mathematical and statistical economics. Even today, to become a fellow of the Econometric Society is to join the elite of economics theorist and econometricians (a term which now has a narrower, statistical focus than it did in 1933). Frisch was the first editor of the society's journal, Econometrica, still reckoned among the top five economics journals.

Frisch was great coiner of neologisms. He originated not only econometrics, but the terms microeconomics and macroeconomics. Most people regard Keynes as the originator of this distinction. He certainly never used the terms, though he drew the distinction between the economics of individual or firm-level decisions, which we now regard as microeconomic, and the determination of output in the economy as a whole, which we regard as macroeconomic. Frisch drew a similar distinction, earlier perhaps than Keynes, and clearly invented the terminology. ${ }^{3}$

Frisch thought that we should start with a macroeconomic model that worked with broad aggregates (GDP rather than an individual's income, for example) to determine the context for a microeconomic model of individual behavior. This is an inversion of the

\footnotetext{
${ }^{3}$ Frisch (1933) uses microdynamic and macrodynamic in a manner nearly equivalent to current usage of microeconomic and macroeconomic. At roughly the same time, he used their Norwegian equivalents, mikroøkonomiske and macroøkonomiske in a set of widely circulated, mimeographed lectures (Frisch 1933/34). Frisch's coinages appear to have spread through the early meetings of the Econometric Society.
} 
manner in which recent economists think. For them, the ideal is to start with microeconomic analysis and build up individual by individual to the behavior of the economy as a whole. Frisch rejected that idea. He conceded that we could imagine in principle a very complex economic model in which every individual and firm was modeled. But such a model would be of no practical use.

Here again, he conceived of analogies with physics. To model the behavior of a single charged particle, the physicist conceives of it as being situated in a field that is the aggregate product of all the charged particles in a system.

\section{TINBERGEN}

Tinbergen was born in 1903 in the Hague. He studied physics, and his doctoral supervisor, the eminent physicist Paul Ehrenfest, suggested that he apply physical analysis to economic problems. The result was a dissertation whose English title is "Minimization Problems in Physics and Economics."

Frisch was primarily interested in the more theoretical problem of characterizing dynamics and the epistemological problem of discovering the right methods for working backwards from available economic data to the specification of an economic model. Tinbergen's interests were less detached from the beginning. He wanted to use economic models for policy. Tinbergen (1937) created the first econometrically estimated macromodel - a model of the Dutch economy - in the mid-1930s. On the basis of this achievement, the League of Nations, which had undertaken a larger project on the causes and cures of the business cycles - a response to the worldwide effects of the Great Depression - commissioned Tinbergen (1939) to create the first macroeconometric model 
of the United States, which was published on the eve of World War II. Tinbergen's model contained 48 equations and was estimated without the benefit of modern electronic computers. “It is strange,” Keynes (1939, p. 568) observed, “that [Tinbergen’s book] looks ... to be the principal activity and raison d'être of the League of Nations” on the eve of the Second World War.

\section{The Medical Vision}

In contrast to Frisch and Tinbergen, physics did not animate Keynes’s research strategy. He was not hostile to mathematics generally, having read mathematics at King's College, Cambridge and graduated $12^{\text {th }}$ wrangler. His fellowship essay for King's was later published as his Treatise on Probability. Economics was not in Keynes's course of study; it was in his blood. When Keynes was student, economics formed part of the moral sciences tripos and was not an independent course of study. Keynes's father was himself a Cambridge economist; and Keynes absorbed economics both from formal study and from being dandled, as it were, on the knee of that Cambridge hero Alfred Marshall.

As an economist, Keynes is known so much in the caricatures of the potted history with which I began, that I want to state what seem to me to be the key points of his approach.

\section{THE FALLACY OF COMPOSITION}

Unlike the economics of Adam Smith, which focused on the wealth of nations, or the economics of $19^{\text {th }}$ century neoclassical economists, such as William Stanley Jevons, which focused on markets, much of modern economics sees the most basic economic 
problem as the one faced by Robinson Crusoe: to do the best one can with scarce resources. For Jevons the game changes as soon as Friday arrives and opens up the possibility of trade. And for Keynes (and Smith), it's a new game altogether if we start to think about Friday's tribe - a whole economy.

For Keynes people are heterogeneous - each is situated differently, each has different tastes, different capacities, different beliefs. Yet, they form a society. And extending our reasoning from individual interactions to the whole economy is misleading. It commits a fallacy of composition. The quickest way for an individual from New Orleans to Baton Rouge is Interstate 10; but it is not the quickest way to get the whole population of New Orleans to Baton Rouge.

A key fallacy of composition in economics is a false analogy from elementary exchange to the economy as a whole. Robinson Crusoe's and Friday's different skills and different endowments give rise to mutually beneficial trade, and there is never any reason other than wanting to enjoy sleep or meal or a swim that they should be unemployed. But for Keynes, an economy as a whole is more like Mandeville’s grumbling hive in the Fable of the Bees (1914): private virtue (parsimony and restraint) produces public vice (economic collapse). A Mercedes sportscar or dinner at a fine restaurant is a dispensable luxury, but if enough of us dispense with such luxuries the autoworker and the busboy go without their dinner: As Keynes puts it, "the gay of tomorrow are absolutely indispensable to provide a raison d'être for the grave of to-day" (General Theory, pp. 105-106). Unlike Robinson and Friday, workers in a complex economy can be unemployed; the economy can operate at less than full capacity.

Keynes was keenly aware that the complexity of the economy depends on the 
institution of money, which allows us to obtains goods from people we'll never know, living lives that we can hardly imagine, in places we'll never see. Robinson and Friday may be selfish, but in an obvious sense they work for each other. If they save, they save by laying up stores. We too work for each other, but only indirectly. Directly, we work for money. And when we save, we save money, and do not demand the work of others. The process of my abstaining from spending leading to another's loss of income and his abstaining from spending, leading to still another's loss of income ... .and so on is Keynes's famous investment multiplier. The multiplier works the other way too expenditure (yours or mine or the government's) gives some people income which, if they spend it, gives other people income ... .and so forth. Theinvestment multiplier is the intellectual basis for President Obama’s stimulus package.

Keynes's important analytical insight is that it just won't do to believe that the private sector will always and everywhere find and effect every valuable exchange. That would imply that the unemployed are dissembling: they say that they want to work, but really they are on vacation.

\section{UNCERTAINTY}

The multiplier explains the process of getting into and out of trouble, but what started the trouble in the first place? Keynes's answer (surprisingly like that of the Austrian economists - often his most vocal opponents) is time and ignorance. The future matters to economic decisions, but we cannot know the future. Institutions have evolved to cope with time and ignorance - insurance, for example. As a chairman of two insurance companies and the author of a Treatise on Probability, Keynes understood insurable risk. 
The casino cannot predict each spin of the roulette wheel; the life insurance company cannot predict the day of each death; but the averages and their variability are known precisely. You take a chance on roulette; the casino calculates its return.

Keynes pointed out in 1937 that risk is not to be confused with uninsurable uncertainty.

the prospect of a European war is uncertain, or the price of copper and the rate of interest twenty years hence, or the obsolescence of a new invention, or the position of private wealth owners in the social system of 1970. About these matters there is no scientific basis on which to form any calculable probabilities whatever. We simply do not know. [Keynes 1973, pp. 113-114]

Keynes would no doubt see the onset of our latest financial collapse in the unfounded valuation of mortgage-backed financial derivatives as the result of an intellectual error confusing insurable risk with uninsurable uncertainty.

How are we to cope with such radical uncertainty. For Keynes (1973, pp. 113114) a conventional response is better than paralysis: "the necessity for action and for decision compels us as practical men to do our best to overlook [uncertainty] and to behave exactly as we should if we ..." could calculate the prospects and the risk. Such a calculation requires a view of those prospects; yet they too are uncertain, and "sanguine temperament and constructive impulses” determine our positive evaluation of them:

If human nature felt no temptation to take a chance, no satisfaction (profit apart) in constructing a factory, a railway, a mine or a farm, there might not be much investment merely as the result of cold calculation. [Keynes 1936 p. 150]

Elsewhere Keynes refers to "the spontaneous urge to action rather than inaction" as animal spirits. (Contrary to what many economists believe, Keynes did not coin this term - now revived in George Akerlof's and Robert Shiller’s (2010) book of the same name: it is originally a term from now obsolete biology, which was already in common 
usage when Jane Austen’s describes the frivolous Lydia Bennett of Pride and Prejudice as having "high animal spirits.”) The conventional response to uncertainty is sometimes not enough:

if the animal spirits are dimmed and the spontaneous optimism falters, leaving us nothing but mathematical expectation, enterprise will fade and die; - though fears of loss may have a basis no more reasonable than hopes of profit had before. [Keynes 1936, pp. 161-162]

He doesn't put it this way, but there is an expectations multiplier as well as an investment multiplier that can turn a boom into a bubble or a slump into a rout.

The most common convention of financial markets - stick with the herd exacerbates our troubles: "Worldly wisdom teaches that it is better for reputation to fail conventionally than to succeed unconventionally” (Keynes 1936, p. 158). When expectations all point only one way, the herd follows and the market booms ... or crashes. "Speculators may do no harm as bubbles on a steady stream of enterprise. But the position is serious when enterprise becomes the bubble on a whirlpool of speculation. (Keynes 1936, p. 159). Keynes was himself a speculator, albeit an unconventional one who made a deal of money for himself and for King's College betting against the herd. But Keynes thought that a more conventional America was especially vulnerable:

Americans are apt to be unduly interested in discovering what average opinion believes average opinion to be; and this national weakness finds its nemesis in the stock market. . . [A]n American ... . will not readily purchase an investment except in the hope of capital appreciation. . . he is, in the [this] sense, a speculator. Speculators may do no harm as bubbles on a steady stream of enterprise. But the position is serious when enterprise becomes the bubble on a whirlpool of speculation. . . [T] he best brains of Wall Street have been . . . directed towards [speculation rather than directing investment to its most profitable uses]. [Keynes 1936, p. 159].

English chauvinist that he was, Keynes nevertheless thought that instability was the "scarcely avoidable outcome of our having successfully organised 'liquid' investment 
markets.” And elitist that he was, it was popular access to financial markets that made the problems worse:

the sins of the London Stock Exchange are less than those of Wall Street . . . not so much [because of] differences in national character, as [because of]. . . the fact that to the average Englishman Throgmorton Street is, compared with Wall Street to the average American, inaccessible and very expensive. [Keynes 1936, p. 159].

Keynes was by no means an irrationalist; the market may ultimately conform to what rational calculation dictates. Yet, he is reputed to have remarked, "Markets can stay irrational longer than you can stay liquid.”

\section{INDIVIDUAL CHOICE}

In stressing the fallacy of composition and uncertainty - aspects of the economy that traditional economics had largely neglected - Keynes by no means rejected traditional economic analysis. His General Theory is constructed out of a series of functions describing the behavior of labor, investment, money holdings, and consumption. For most of these functions, his analysis is built on the a careful analysis of individual choice in a manner familiar to all students of Marshall and all modern microeconomists.

Take one example, his analysis of the demand for money (or as he calls it, “liquidity preference”). Keynes suggests that each person has an expectation of what interest rate is normal. Anyone whose expectation is below the market rate is a "bull" one who expects rates to fall and, therefore, expects to take a capital gain on long-term bonds. Anyone whose expectations are above the market rate is a "bear" - one who expects rates to rise and, therefore, expects to take a capital loss. The bulls want to hold bonds; the bears want to hold money (which, for Keynes, includes short-term bonds, often counted as “cash” by financial-market players). The market rate is that rate that 
balances the bulls and the bears.

The point of this example is not the details, but to notice that Keynes appeals to profit-maximizing behavior exactly as any microeconomist would. What's more, Keynes does not follow Frisch or Tinbergen in aggregating. He does not look at the average behavior of individuals, nor does he add up all the supplies of money or all the demands for the money. Instead, the market rate of interest turns out to be what some particular individual believes the normal rate to be. In principle, we should be able to pick out the particular individual whose normal rate in fact defines the market rate. Keynes's object is macroeconomic analysis, but unlike Frisch and Tinbergen, he does not appeal to data that abstract from individuals, but to relationships that are fundamentally grounded in recognizable individual behavior.

Keynes's analysis of consumption is different. It is still deeply grounded in individual choice. But unlike the other functions, Keynes appeals not only to maximization of obviously economic factors, but also to a wider range of human behaviors and motivations: precaution, foresight, calculation, improvement, independence, enterprise, pride, avarice, enjoyment, shortsightedness, generosity, miscalculation, ostentation, and extravagance (Keynes 1936, p. 108). This is the Keynes who was the intimate of Lytton Strachey, Virginia Woolf, Duncan Grant and the other writers and artists of the Bloomsbury Group: patterns of consumption are not merely instrumental, but are a closer reflection of the ultimate human values than are returns on a financial portfolio. All these factors are deeply connected to individual values and individual choice; they are not considerations that are easily reflected in the national accounts. 
Keynes's method of analysis keeps individual people and understandable human behavior front and center. Frisch’s and Tinbergen's methods do not. But Frisch's and Tinbergen's methods allow for quantification and for making sense of economic .

Keynes's method did not.

\section{A Medical Metaphor}

Keynes's approach to economics is richly social and deeply practical. Keynes is not as clearly committed to a metaphor as Frisch and Tinbergen are to the metaphor of the machine. I want to suggest nonetheless that there is an implicitly organic metaphor in his approach. Keynes's teacher, Alfred Marshall, had himself toyed with analogies between economics and biology. But it seems to me that medicine - a sort of applied biology provides a closer analogy to Keynes’s approach. I don’t know that Keynes ever explicitly frames any biological metaphor, although he does, at least once, point to a minor medical specialty as a model: "[i]f economists could manage to get themselves thought of as humble, competent people, on a level with dentists, that would be splendid" (Keynes 1931[1972], p. 332).

Keynes does, however, clearly reject the mechanical metaphor:

The object of our analysis is, not to provide a machine, or method of blind manipulation, which will furnish an infallible answer, but to provide ourselves with an organized and orderly method of thinking out particular problems ... . K Keynes 1936, p. 297].

And he ties that rejection specifically to policy analysis: He endorses

[t]he reasonable doubts of practical men towards the idea that the Federal Reserve System has the power to raise or lower the price level by some automatic method, by some magic mathematical formula [Keynes 1930b[1971b], p. 305].

We don't understand the economy in the same manner as we understand a mechanical 
system:

[t]he possible varieties of the paths which a . . cycle can follow and its possible complications are so numerous that it is impracticable to outline all of them. One can describe the rules of chess and the nature of the game, work out the leading openings and play through a few characteristic end-games; but one cannot possibly catalogue all the games which can be played. [Keynes 1930a[1971a], p. 253]

Keynes's metaphor is here not specifically organic, but he is alive to the complexity of even the relatively simple situations of games; and, as we shall see, his attitude to towards policy is that of a physician rather than an engineer.

\section{Birth of Modern Macroeconomics}

I don’t want to exaggerate the divide between Keynes and Tinbergen and Frisch. Keynes’s approach keeps individual human behavior at the center. Frisch’s and Tinbergen's approach supports practical data-collection and quantification. The tension between these approaches is the mainspring of the history of macroeconomics after World War II.

Keynes famously attacked Tinbergen’s (1939) econometric model of the United States, based in large measure on the presumed requirement that Tinbergen's statistics should capture a complete list of causes and that the relationships among the variables to be quantitatively stable - in his view an utter impossibility. Klein (2004, p. 156) later characterized Keynes’s treatment of Tinbergen as “shabby,” and he praised Tinbergen’s good nature in expressing “no ill will toward Keynes.” Tinbergen indeed took inspiration from the General Theory for his later work. As Tinbergen went, so did the profession. Within a few years of Keynes’s untimely death in 1946, Keynesian economics became less associated with a direct acquaintance with the General Theory than with Sir John Hicks’s (1937) simplified, aggregate reconstruction of its main functional relationships, 
known to generations of economics students as the IS-LM model.

The IS-LM model deals with aggregates. One can no longer, in principle, pinpoint the individual people. But then, one never could in practice. The IS-LM model licensed a fully aggregated version of Keynesian economics and gave free rein to the mechanical metaphor, which was made flesh in A.W.H. Phillips's machine - a model of the economy built from pumps, reservoirs, plastic tubes, and colored water. ${ }^{4}$ While Phillips prefers hydraulics to oscillating pendulums, the metaphor is mechanical just the same.

The American economist Lawrence Klein published his doctoral dissertation under the title The Keynesian Revolution (1947). Like Hicks, Klein tried to connect Keynes's principal insights to the older economic tradition, now largely encapsulated under Frisch's heading of microeconomics, to form the basis for a sound aggregate macroeconomics. Klein worked briefly at the Cowles Commission, which was developing macroeconometric modeling in the Tinbergen mold. The Phillips machine was an analogue model and used mainly as a teaching device illustrating macroeconomic principles. But just at the period that Klein began to work, the digital computer was invented. Macroeconometric modeling developed in lockstep with computing technology. Macroeconometric models grew increasingly complex: Tinbergen’s model of 1939 contained 48-equation models; Klein’s Brookings Model of 1965 contained 150 equations; later models were still larger. ${ }^{5}$

These models were referred to as "Keynesian.” But, in truth, they owe considerably more to Tinbergen and to Hicks than to Keynes.

\footnotetext{
${ }^{4}$ Phillips (1950); see also Boumans and Morgan (2004).

${ }^{5}$ Duesenberry et al. (1965) provides a contemporaneous description of the Brookings Model; see Bodkin, Klein, and Marwah (1991) for a general history of macroeconometric modeling.
} 


\section{Policy and Policymaking}

Just as mechanics in physics is the basis for the applied science of engineering, macroeconometric models were created with policy applications in mind. From the beginning of his studies, Tinbergen conceived of his work in economics as supporting economic planning. In the 1950s, he wrote three books on the methodology of economic policy (Tinbergen 1954, 1955, 1956). Tinbergen introduced economists to the distinction between the objects of policy (targets) and the means of influencing the path of the economy towards those objects (instruments). His distinction is regarded as fundamental among economists. And it is heard constantly in recent discussions of monetary and fiscal policy the press, in the American Congress, as well as in Brussels and Frankfurt, and among economists. For example, it is the frame for unconventional or nonstandard monetary policy - the so-called quantitative easing that is the talk of central banks around the world.

The targets-and-instruments approach is essentially the approach of an engineer: we can analyze rocket guidance in exactly the same way. With the targets-andinstruments approach, the economist as policy advisor stands outside the machine: he observes the behavior of the economy and tries to capture it a macroeconometric model; he manipulates policy instruments (e.g., interest or tax rates) using the model to predict the results of his choices.

Keynes's strategy is different. To return to his analogy with chess, the economist does not stand above the game. Instead, the economist is just another player of the board - say, the king's bishop. The future is not determined by the predictions of a formal 
model. He faces uncertainty, just as any other player does. Yes, he possesses a chess manual, but it is one that has been written, not from the overarching perspective of the chess master, but from the ground-level view of the bishop. Acquisition of economic knowledge occurs within the game. It is necessarily partial, bound by particular perspectives, and subject to debate. Yes, Keynes and his fellow economists are the bishops. They argue and debate. They possess the arcane knowledge of the manuals of play; in that sense they know more than the other players. Their theories may be cast in an over-arching perspective, but this is merely a projection from inside the game, and not the product of a standpoint that they somehow occupy above the game. The test of their theories is largely the success of their policy advice: does their side win the game? But tests of that sort can be run only if the economists can convince the kings, queens, and even the pawns to follow their manual. Doubts, Keynes wrote, about the efficacy of policy cannot be dispelled merely by appealing to economic theory or models; "they can only be dispelled by the prolonged success of an actual attempt at scientific control” (1930b[1971b], p. 309).

Both Frisch and Tinbergen came to agree with Keynes that estimated macroeconometric relationships were not sufficiently stable over long periods of time to projected far into the future. They reacted to this realization as engineers would. There is even an apt political pun. In the depths of the Great Depression at a time when the American South was essentially an underdeveloped country, mired in poverty, President Franklin Roosevelt took at our of the Tennessee Valley. What did he say when he saw the Tennessee River for the first time? "Dam it!" That is the engineers vision: If the world is not how we would like it be, change the world. Both Frisch and Tinbergen 
advocated central planning. And Tinbergen even served in the Dutch Central Planning Bureau, starting in the 1950s.

Frisch rejected any biological metaphor. The problem of cycles was not some sort of "bacillius cyclicus” (Louçã 2007, p. 131). We should not look for a disease nor should we seek a cure. Rather than as a physician, Frisch saw the economist as a "social engineer” (Louçã 2007, p. 296). The economic problem was that there were too many independent agents (Louçã 2007, p. 289). The solution was to use economic planning to circumvent "the human obstacle to human progress" (Louçã 2007, p. 297).

In contrast, Keynes rejected the Corps-of-Engineers approach. He did not want to channel the unruly streams of society along simpler, more rational paths. Unlike Frisch and Tinbergen, he was not a socialist, but a liberal; not a central planner, but a social doctor. The metaphor of the body politic and the body economic suit him better than the metaphor of the machine.

Keynes wrote about the socialization of investment; but, by this, he mainly meant that, when private demand was inadequate, the government should nudge it along through monetary and fiscal policy. It did not mean that the economy would be controlled comprehensively from the center. Recognizing the complexity of the economy, he tried to suggest medicine and, like any physician, advocated watching the course of the disease and adjusting the treatment empirically based on the current state of the patient.

Desperate times call for drastic action, so that Keynes was more willing to engage in comprehensive intervention during the Great Depression than at other times. Yet, it is striking that Keynes bucked the conventional wisdom and placed his faith in the private sector, the price system, and monetary and fiscal policy to rise to the challenge when he 
advised against rationing in Britain in World War II. Frisch rejected Keynes's mild interventions as too weak to met the fundamental economic problem.

\section{The Continuing Clash of Metaphors}

It is outside the scope of my talk to address more modern developments in detail. But it is worth noting that recent macroeconomics can be seen as an attempting reconciliation of the mechanical and organic metaphors. The new classical revolution of the 1970s, although framed as "anti-Keynesian," was more directly an assault on macroeconometric models in the tradition of Tinbergen and Klein. ${ }^{6}$

New classicals called for models that placed expectations and optimal choice by individuals back in the center of macroeconomic analysis. They rejected the view that the policymaker stands outside the economic system. In these respects they stood closer to Keynes than they realized. But in stressing quantitative and mathematically closed models, they stood firmly in the mechanical tradition of Frisch and Tinbergen. For instance, in a famous passage, Lucas wrote:

Our task ... is to write a FORTRAN program that will accept specific economic policy rules as "input" and will generate as "output" statistics describing the operating characteristics of time series we care about, which are predicted to result from these policies. [Lucas 1980, p. 288]

Keynes could never have agreed.

Combining individual human decision-making with the mechanical models is difficult. Just as Frisch had observed in 1933, there are too many individuals in the economy. His solution was to invent aggregate macroeconomics. Keynes's solution was provide only a qualitative analysis of the connection between the individual and the

\footnotetext{
${ }^{6}$ See, e.g., Lucas (1976).
} 
economy as a whole and to adopt the pragmatic stance of the empirically minded physician in matters of policy. The new classicals and their fellow travelers, the new Keynesian, have instead applied highly simplified microeconomic models - models in which one or a few agents stand for, or represent, individual choice - to aggregate data. These are now the most popular models in economics and the ones that have been most vilified by those who believed that the economics profession failed us in the Great Recession. 


\section{References}

Akerlof, George A. and Robert J. Shiller. (2010) Animal Spirits: How Human Psychology Drives the Economy, and Why It Matters for Global Capitalism. Princeton: Princeton University Press.

Bodkin, Ronald G., Lawrence R. Klein, and Kanta Marwah (1991) A History of Macroeconometric Model-building. Aldershot: Edward Elgar.

Boumans, Marcel and Mary S. Morgan. (2004) "Secrets Hidden by Two Dimensionality: The Economy as a Hydraulic Machine,” in Soraya de Chadarevian and Nick Hopwood, editors, Models: The Third Dimension of Science. Stanford: Stanford University Press, pp. 369-401.

Duesenberry, James S., Gary Fromm, Lawrence R. Klein, and Edwin Kuh, editors. (1965) The Brookings Quarterly Econometric Model of the United States. Chicago: Rand McNally.

Frisch, Ragnar. (1933) "Propagation Problems and Impulse Problems in Dynamic Economics,” in Economic Essays in Honor of Gustav Cassel: October 20 th 1933. London: George Allen and Unwin, pp. 171-205.

Frisch, Ragnar. (1933/1934) Forelesninger holdt $1933^{I I}$ og $1934^{I}$ over Makrodynamik, mimeographed lecture notes.

Hicks, John R. (1937) “Mr. Keynes and the Classics,” Econometrica 5(2), 147-159.

Keynes, John Maynard. (1930a[1972a]) A Treatise on Money, vol. 1: The Pure Theory of Money (The Collected Writings of John Maynard Keynes, vol. 5). London: Macmillan.

Keynes, John Maynard. (1930b[1972b]) A Treatise on Money, vol. 2: The Applied Theory of Money (The Collected Writings of John Maynard Keynes, vol. 6). London: Macmillan.

Keynes, John Maynard. (1931[1972]) Essays in Persuasion (The Collected Writings of John Maynard Keynes, vol. 9). London: Macmillan.

Keynes, John Maynard. (1936) The General Theory of Employment, Interest, and Money. London: Macmillan.

Keynes, John Maynard. (1939) "Official Papers: The Statistical Testing of BusinessCycle Theories,” Economic Journal 44(195), 558-568.

Keynes, John Maynard. (1973) The General Theory and After, Part II: Defense and Development (The Collected Writings of John Maynard Keynes, vol. 14). London: Macmillan.

Klein, Lawrence R. (1947) The Keynesian Revolution. New York: Macmillan.

Klein, Lawrence R. (2004) “The Contribution of Jan Tinbergen to Economic Science,” De Economist 152(2), pp. 155-157.

Louçã, Franciso. (2007) The Years of High Econometrics: A Short History of the Generation that Reinvented Economics. London: Routledge. 
Lucas, Robert E., Jr. (1976) “Econometric Policy Evaluation: A Critique,” reprinted in Lucas (1981), pp. 104-130.

Lucas, Robert E., Jr. (1980) “Methods and Problems in Business Cycle Theory,” Journal of Money, Credit and Banking. 12(4, Part 2), November, 696-715. References to reprint in Lucas (1981), pp. 271-296.

Lucas, Robert E., Jr. (1981) Studies in Business-Cycle Theory. Oxford: Blackwell.

Mandeville, Bernard de. (1714) Fable of the Bees: or, Private Vices, Public Benefits.

Mankiw, N. Gregory. (2008) “What Would Keynes Have Done?,” New York Times 28 November, 2008.

Phillips, A. W. (1950) “Mechanical Models in Economic Dynamics,” Economica , N.S. 17(67), pp. 283-305.

Tinbergen, Jan. (1937) An Econometric Approach to Business Cycle Problems. Paris: Hermann.

Tinbergen, Jan. (1939) Statistical Testing of Business Cycle Theories. Geneva, League of Nations.

Tinbergen, Jan. (1954) Centralization and Decentralization in Economic Policy. Amsterdam: North Holland.

Tinbergen, Jan. (1955) On the Theory of Economic Policy. Amsterdam: North-Holland.

Tinbergen, Jan. (1956) Economic Policy: Principles and Design. Amsterdam, North Holland. 